\title{
THE CONDITION AND RESEARCH OF HISTORICAL AND CULTURAL MONUMENTS ON THE EVE OF THE SECOND WORLD WAR AND IN THE YEARS OF THE WAR
}

\author{
Dilnoza Ulugbekovna Yuldasheva \\ Teacher at the department "The History of Uzbekistan" of Andizhan State University, \\ Andizhan region, Republic of Uzbekistan
}

Article DOI: https://doi.org/10.36713/epra5160

\begin{abstract}
The article analyzes the state and preservation of historical and cultural monuments before and during the Second World War, the direct initiative and leadership of organization Uzkomstaris which is responsible for the protection of historical and cultural monuments in Uzbekistan, using archival materials and scientific literature.

KEY WORDS: Uzbekistan, historical and cultural monuments, protection, ancient city, Uzkomstaris, madrasah, mosque, museum, Ferghana valley.
\end{abstract}

\section{INTRODUCTION}

On the eve of World War II, the study of historical and cultural monuments in Uzbekistan was primarily focused on the registration and protection of historical and cultural monuments in the country. These efforts were made at the direct initiative and under the leadership of Uzkomstaris which at that time was responsible for the protection of historical and cultural monuments in the republic. The special work plan of the Uzkomstaris Committee for 19381942 focused on an important issue - a comprehensive study of the past of the peoples of Central Asia. On the other hand, his important attention was focused on the protection of ancient architectural monuments, as well as other categories of historical monuments (ancient cities, tombs)[1, p.4].

\section{METHODS}

According to this plan, on March 19, 1939, according to the decision of the Organizing Committee of the Central Executive Committee of the USSR №-340, the gates of Bukhara Karshi, Imam, Samarkand, Salokhona, Shergiron, Mazar and the adjacent city wall were removed from state protection and handed over to the city council. Also, Taqi Sarrafon, Kokaldosh madrasah were taken from the state protection and the Ark building was included in the category of museum of republican significance as Bukhara museum. During these years, as in other regions of the country, attention was paid to the scientific study of architectural structures in the Ferghana Valley. For example, during 1938-1939, the architectural monuments of the Ferghana Valley were studied in detail by the architect V.L.Voronina and ethnographer A.K. Pisarchik.

\section{RESULTS AND DISCUSSIONS}

At the same time, this issue has a special place in the research of a group of well-known archeologists I.Ahrorov, N.G.Gorbunova, Yu.A.Zadneprovsky. During this period, more than a hundred monuments of Fergana architecture of the XVI-XIX centuries, located in different district of the valley, were registered. One such monument in the valley is the Khudoyorkhan Palace in Orda, which was built in the second half of the 19th century on a hill in Kokand. The palace occupied a rectangular area of about four hectares and formed a multicourtyard composition [2, p.4]. The palace consisted 
of about 100 rooms, the first half of which was a courtyard with a porch on the outside, in which there was a magnificent hall for reception, a mosque with a separate stage. This cultural monument is one of the most important objects in the Fergana Valley, which has attracted many tourists. Archaeological excavations were carried out in the territory of Chirchik-Angren, Samarkand and Zarafshan valleys of the ancient Sogd region [3, p.5].

In 1939, the old Ishratkhona (second half of the XV century) was analyzed by scientists under the leadership of G.A. Pugachenkova. This historical building, which has a unique art of construction and architectural style, was thoroughly analyzed, and on the basis of the materials collected on it, the museums were enriched with source information. Significant work was done in 1938-1940 on the collection of exhibits in the Museum of History. In particular, a database on industrial enterprises such as the Tashkent Textile Combine, Andizhan Oil Refinery and Ferghana Cotton Ginning Plant has been created. Active researchers of the museum Yu.Burigina and B.S.Sergeev collected materials on land and water reform in Ferghana and the nationalterritorial state delimitation. During the construction of the Huge Ferghana Canal, valuable materials on ethnology and folklore, newspapers dedicated to the excavation of the canal, memoirs, various posters and material items were collected, which in turn were used to promote propaganda work on the construction of irrigation facilities. In addition, archeological materials found during the construction of the Greater Fergana Canal have a special place in the museum collections [4, p.47]. Many exhibits of the Museum of National Economy, which was closed in 1938, were also transferred to the Museum of the History of the Peoples of Uzbekistan. Apparently, there have been cases of mergers in many museums due to economic problems. During the years under study, many historical mausoleums were destroyed as a result of neglect, and some of them were demolished by order of Soviet officials. One of such constructions was the mausoleum of Bobokhoja, a descendant of Qaffol Shoshi, built in the late $16^{\text {th }}$ century in the "double" style [5, p.270]. The mausoleum was demolished in 1939. According to historical evidence, in the middle of the XIX century in front of the Barakkhan madrasah was built the Tashkent mosque ("Tillashaikh mosque"), Muyi Muborak madrasah, mosque (not preserved). At the beginning of the $20^{\text {th }}$ century, the Tillashaikh Mosque was rebuilt and Eshan Babakhan was buried there.

On the eve of the war, the repair and restoration of historical and cultural monuments was not carried out satisfactorily. There was a serious situation in the industry: the state planning committee of the center refused to provide the necessary materials for the repair of buildings - wood, iron and nails [7, p.18] and the work of technical staff was unsatisfactory. As a result, the strengthening and repair and reconstruction of the Jarkurgan tower, which dates back to the XVIII century, was left halfway. The indifference of the Soviet authorities to the preservation of cultural monuments, the failure to complete this work, further accelerated the process of collapse and destruction of the historic tower. It should be noted that even in the difficult conditions of the war, some changes were made in the activities of museums of the republic, including the State Museum of History and Art of the Peoples of Uzbekistan V.V. Struve, M.S. Andreev, A.Yu. Yakubovsky, Well-known scientists such as P. Tolstov, A.Semyonov, K. V. Trever, T.Mirgiyosov acted as members of the Scientific Council [8, p.188]. These scientists, in turn, made an important contribution to the study of existing material and cultural monuments in the republic and their scientific study. There have also been positive changes in the expansion of museums, which play an important role in the preservation of monuments, the formation, reconstruction and use of museum funds for propaganda purposes. In the early 1940s, a number of research works and special researches carried out by the staff of the Uzkomstaris Committee were published in scientific articles, bulletins, periodicals. Most of the publications are based on the results of archeological expeditions in the country, and significant results have been achieved in the historiography of the history of Uzbekistan. In particular, archeological expeditions conducted by archeologists in Khorezm, Bukhara, Varakhsha, Ayritom and other regions have provided new information about the cisterns, found an ancient Stone Age man in the Teshiktash cave and identified a number of ancient finds. The development of local archeologists Ya.G. Gulomov, M.Yu. Saidjanov and T. Mirgiyosov was of great importance in the science of Uzbek archeology and its development [9, p.10].

These scientists made an important contribution to the development of the science of archeology and the recognition of archeological monuments in the world. In June 1940, the Uzbek Committee for the Protection of Ancient, Revolutionary and Art Monuments developed the "Guidelines for the Identification, Record and Protection of Ancient, Revolutionary and Art Monuments" [10, p.1] and approved by the Council of People's Commissars of the USSR. According to this instruction, Uzkomstaris is responsible for the registration, identification and protection of state and local monuments. According to the instructions, Uzkomstaris strictly prohibits the transfer, sale and donation of all types of state-registered monuments. All types of monuments under state protection, 
approved by the Uzbek SSR, were transformed into real estate and nationalized property of the Uzkomstaris Committee. Separately, the repair, restoration and protection of local monuments will be carried out from the budget of local organizations. Uzkomstaris is tasked with recording all types of research work, scientific trips and expeditions. According to the mentioned document, the types of state-registered monuments included [11, p.4], historical-revolutionary monuments; archeological monuments; architectural monuments; monuments of fine arts and sculptures; memorial monuments.

On the eve of the war and in the war years, there is a scientific study of the monuments and mosques - mausoleums, which reflect the traditions and ancient rituals of the Uzbek people. In particular, in October 1940, during a scientific trip to Nurata led by ethnologist A.K. Pisarchik, a number of information about the ancient monument in the city of Karmana was collected. This cultural-architectural mausoleum (10 ${ }^{\text {th }}$ century) was named Mirsaid Bahrom and was registered by an ethnologist [12, p.19]. Due to the difficult economic conditions during World War II, many museums in the republic were not financially self-sufficient. This, in turn, has led to a reduction in the activities of museums and the generalization of some of them. During this period, the polytechnic exhibition was closed and the Art Museum was suspended, and in November 1941 it was added to the Museum of History of the USSR together with the Navoi Museum. As a result, the combined museums were tasked to fully identify local resources and study them in detail from a scientific and practical point of view. The Museum of History and Art donated its halls to industrial enterprises and in late 1941 moved to the former Polytechnic Museum building. In addition, during the war years, the issue of architectural monuments of Central Asia, in particular Uzbekistan, and their history, condition, specific oriental methods of construction of madrasas and mosques were included in the scientific analysis as a separate study. In particular, the researches of ethnographers, archeologists, art historians such as L.Voronin, B.Zasipkin, L.Rempel, B.Baklanov, V.Voronina, G.Gaganov, Central Asian architecture, history and culture of cities, ethnographic monuments and ancient monuments.

Many scientific works on the history of as noted above, even in the difficult economic situation during the war years, valuable archeological excavations were carried out in the republic. Archaeologists have carried out excavations at the Mirzo Ulugbek Observatory, as well as in its suburban gardens, Afrosiyab and Varakhsha. Archaeological and ethnographic expeditions were revived in Khorezm under the leadership of well- known archeologists Ya.G. Gulomov and S.P. Tolstov, rare archeological monuments of ancient Khorezm civilization were opened and involved in scientific research [13, p.490]. The mistakes of the Soviet economic and cultural organizations in the protection of monuments required the necessary measures to preserve the existing art, historical and cultural sites in the republic.

In particular, on December 29, 1940, the Bukhara Regional Executive Committee adopted a resolution "On measures to protect ancient, revolutionary and art monuments in Bukhara region and the city" $[14, \mathrm{p} .35]$. According to him, the tasks were set to implement measures to protect the ancient and Muslim architectural monuments in Bukhara. However, the work to be done here in the field of archeology was not carried out in a planned manner. In particular, the excavations that were to be carried out to inspect the foundation of the Minorai Kalon were left unfinished due to lack of capital funds. Of the planned and important works, only the excavations in the north-western part of the Mir Arab madrasah and under the roof of the Magoki Attori mosque were carried out. Important practical work has been done on the comprehensive study and protection of the existing revolutionary monuments in the country. For example, on January 1, 1941, the Committee of Uzkomstaris took into account 58 monuments in the revolutionary sector and began a comprehensive study of them. They were mainly associated with the uprisings of 1905-1916, the October coup, the civil war. In short, the main activity of the sector was the study of the "history" of the uprisings that took place under colonial conditions and organized revolutionary movements.

The regional branches of the Committee have also taken important measures in the field of repair and restoration of historical monuments. At the initiative of the branches, 25 monuments were repaired at a cost of 246,835 rubles. Carrying out repair work on the monuments under state protection, in turn, served to restore the appearance of the complexes to their original state. Although it was officially noted that all historical, artistic and revolutionary monuments of historical and artistic value in the republic were protected by the Uzkomstaris Committee, in early 1941 the organization included about 90 architectural, revolutionary and artistic monuments [15, p.58]. At the same time, Uzkomstaris was tasked with repairing a number of architectural and cultural monuments. On this basis, a capital of 20,000 rubles was allocated for the financing of a special exhibition dedicated to May 1, 1941 in the republic. The Samarkand branch of the Committee was allocated 425,000 rubles for the repair of a number of architectural monuments of the Timurid period, 
including the Gori Amir, Ishratkhana, Shahizinda mausoleums, Ulugbek Observatory and Madrasah, Bibikhanum Mosque and Mausoleum and Barakkhan Madrasah [16, p.1].

Measures to protect historical and cultural monuments in the southern region of the country, in particular in Surkhandarya, are explained by a special resolution of the Executive Committee of the Surkhandarya District Council of Workers' Deputies on January 18, 1941 "On the state of cultural monuments in Surkhandarya district" [17, p.9]. According to him, the Kokildora and Kyrgyz monuments in Termez district, the Jarqurghon tower and the madrasah in Denau district were transferred to Termezkomstaris. The text of the resolution also highlights the measures taken to protect historical and cultural monuments in the region, their full registration, preservation, the organization of ethnological and archeological expeditions, as well as shortcomings in this area. The activities of the Uzkomstaris Committee include the organization of anniversaries of great thinkers of the Uzbek people and their holding throughout the country. By holding such practical events, the birthdays of Uzbek thinkers were celebrated, and the committee took the initiative and was responsible for holding these responsible events.

In this context, on April 23, 1941, the Central Committee of the Communist Party of Uzbekistan and the Council of Ministers of the USSR adopted a resolution "On measures to celebrate the $500^{\text {th }}$ anniversary of Alisher Navoi". One of such important tasks related to the celebration of this anniversary, as noted above, was entrusted to the Committee Uzkomstaris. In particular, the Uzkomstaris committee was instructed to prepare for publication the collection "Architectural image of Samarkand in the time of Alisher Navoi" and its publication in 5,000 copies from the beginning of the anniversary. Thus, a special commission was set up to make an important contribution to the scientific circulation of previously non-existent cases in anthropology and epigraphy. During the war years, the organization and organization of museum work in the republic was one of the urgent tasks. Even in difficult conditions, the organization of mobile and stationary exhibitions by the staff of the Museum of the History of the Peoples of Uzbekistan has gradually become popular. One of such mobile exhibitions was organized in 1942 under the name "Courage of our Motherland". The exhibition reflected the courage of Uzbeks in World War II.

The museum staff also organized talks and lectures on the courage of the Uzbek people behind the front, the international situation in industrial enterprises and educational institutions. Accordingly, special attention was paid to the expansion of public education and advocacy in the activities of museums. In particular, the organization of exhibitions in the Museum of History has become more active: the exhibition "Folk Art of Uzbekistan", founded in 1943, has become notable. The exhibition focuses on the centuries-old examples of applied arts of the Uzbek people, folklore, art and works of art [18, p.46].

In 1943, the Uzbek Committee for the Protection of Ancient, Revolutionary and Art Monuments under the Uzbek Soviet Socialist Republic became the only cultural organization in the country, which also carried out a number of practical work on the protection of ancient and art monuments. In particular, this year Uzkomstaris managed to restore and repair the mausoleum of Amir Temur, an architectural monument of Uzbekistan in the XIV century. In October and November of this year, 18 key staff members of the Uzkomstaris Committee were sent here for repairs, and an additional 7 people were sent on a contract basis [19, p.4]. In the same year, research institutions covering various fields of science were established in the country. In particular, in 1943 there were 19 research institutes, 23 different scientific stations, 3 observatories, 11 museums and 6 different research institutions in the territory of the republic. The establishment of research institutions has opened a wide way for a comprehensive study of historical and cultural monuments of the republic, their protection. The establishment of the Academy of Sciences as a coordinating center for research in the country has served as a basis for significant changes in the activities of museums.

After the decision of the Council of People's Commissars of the Union on September 27, 1943 "On the establishment of the Academy of Sciences of the Uzbek SSR", the Museum of History, along with other institutions, was separated from the Museum of Art as a central museum for research and political education was included in the Academy of Sciences of the USSR under the name of the museum [20, p.9]. In addition, the Museum of Nature was included in the structure of the Higher School of Sciences. In turn, a number of new opportunities have been created in the activities of museums of the republic in the organization of research work, as well as significant changes in the protection of cultural monuments.

\section{CONCLUSION}

In conclusion, during the years of World War II and on its eve, there were some changes in the system of protection of historical and cultural monuments in Uzbekistan. The hardships of the war also had a negative impact on the system of preservation of cultural monuments: the number of museums was reduced and most of them were 
merged. In turn, the scope of activities of the Uzkomstaris Committee has become more active than in the past. The monuments which embody the historically specific type of archeological, art and revolution of all historical and artistic value in the republic were transferred to the disposal of the committee and protected.

\section{REFERENCES}

1. National Archive of Uzbekistan, Fund R.2296, List 1, Collection 163, page 4.

2. National Archive of Uzbekistan, fund R.394, list 1, collection 121, volume 145 .

3. National Archive of Uzbekistan, Fund R.2296, List 1, Collection 163, page 5.

4. Sodikova N.S., Buryakov Yu.F. Treasure of historical monuments.-Tashkent: Science, 1981. P.47.

5. National encyclopedia of Uzbekistan. Volume 11.-Tashkent: UzME, 2005. -P.269-270.

6. http://uzbekmuzey.uz/obidalar/hazrati imom majmuasi.html

7. National Archive of Uzbekistan, Fund R.2296, List 1, Collection 251, page 18.

8. Sodikova N. Treasure of cultural monuments. Tashkent: Fan, 1981.page.188.

9. National Archive of Uzbekistan, Fund R.2296, List 1, Volume 163, page 10.

10. National Archive of Uzbekistan, Fund R.2296, List 1, Collection 305, page 1.

11. National Archive of Uzbekistan, Fund R.2296, List 1, Collection 305, page 4.

12. National Archive of Uzbekistan, Fund R.2296, List 1, Collection 312, page 19.

13. New history of Uzbekistan. The second book. Uzbekistan during the Soviet colonial period.Tashkent: Shark, 2000.p.490.

14. National Archive of Uzbekistan, Fund R.2296, List 1, Collection 312, page 35.

15. National Archive of Uzbekistan, Fund R.2296, List 1, Collection 274, page 58.

16. National Archive of Uzbekistan, Fund R.2296, List 1, Collection 274, page 16.

17. National Archive of Uzbekistan, Fund R.2296, List 1, Collection 312, pages 8, 9.

18. National Archive of Uzbekistan, Fund R.2296, List 1, Collection 322, page 46.

19. National Archive of Uzbekistan, Fund R.2296, List 1, Collection 341, page 4.

20. National Archive of Uzbekistan, Fund R.2296, List 1, Collection 341, page 9. 